УДК $575.11+577.21+577.213 .3+616.832-009.55$

N.V. HRYSHCHENKO, L.A. LIVSHITS

Institute of Molecular Biology and Genetics, NASU, 150 Zabolotnogo str. Kyiv, Ukraine, 03680, livshits@imbmg.org.ua

\section{ANALYSIS OF 17p11.2 CHROMOSOME REGION REARRANGEMENTS IN CMT1 PATIENTS FROM UKRAINE}

Two intercomplementary methods of 17p11.2 duplication/deletion identification have been elaborated: STR allelic variants analysis and direct PMP22 gene dosage measuring by means of quantitative Real-Time PCR. It has been carried out detection and analysis of $17 p 11.2$ chromosome region rearrangements in CMT1 patients from Ukraine. It has been registered the high level of de novo cases with 17p11.2-duplication. It has been shown the 17p11.2 chromosome region duplication/deletion association with CMT1A and HNPP clinical phenotypes which may be used in differential diagnosis of this type of CMT polyneuropathy.

(c) N.V. HRYSHCHENKO, L.A. LIVSHITS, 2009
Introduction. Charcot-Marie-Tooth disease (CMT) and related neuropathies (hereditary neuropathy with liability to pressure palsies [HNPP] and Dejerine-Sottas disease [DSS]) are clinically and genetically heterogeneous group of sensorineural polyneuropathies. CMT hereditary neuropathy syndrome is the most common genetic cause of neuropathy with a frequency of 1 in 2500 [1].

The first level of classification concerns the mode of inheritance: autosomal dominant, X-linked and autosomal recessive. The second level of classification in each subgroup depends upon the neuropathy disorder process. CMT is traditionally classified into two types, demyelinating (CMT1) and axonal (CMT2) forms according to electrophysiological criteria The diagnostic criteria for Charcot-Marie-Tooth disease type 1 are motor nerve conduction velocities under $38 \mathrm{~m} / \mathrm{s}$, on ion bulbs and signs of demyelination and remyelination in sural nerve biopsies, and no clinical or histopathological evidence of other diseases associated with demyelinating polyneuropathies. CMT2 is characterized by normal or slightly reduced motor nerve conduction velocities [2].

Many loci and genes have been identified in each CMT subtype. Autosomal dominant demyelinating CMT can be due mostly to PMP22 gene 17p11.2-duplication (CMT1A) but also to other genes such as P0 (1q22), LITAF (16p13) and EGR2 (10q21) mutations. Approximately $20 \%$ of all individuals presenting neuromuscular clinics with a chronic peripheral neuropathy have CMT type 1A (PMP22 duplication) as the cause of the neuropathy [3]. Prevalence is about 1 in 3300 people. The uncommon allelic variant of CMT1A is Herditary Neuropathy with Liability to Pressure Palsies (HNPP).

First described by De Jong in 1947 HNNP is an autosomal dominant inherited disease characterized by recurrent painless focal neuropathies. Chance et al identified a $1.5 \mathrm{Mb}$ reciprocal deletion encompassing the PMP22 gene which is responsible for the disease [4]. The same region (17p11.2) duplication leads to distinct clinical type CMT1A. The CMT1A duplication and HNPP deletion represent products of unequal crossing over and a reciprocal recombination between flanking 24-kb homologous sequences termed CMT1A-REPs [5, 6] (Fig. 1).

The differential DNA-diagnostic of CMT1A/ HNPP is based on the $17 \mathrm{p} 11.2$ duplication/deletion or PMP22 gene point mutation detection. 
The methods used in diagnostic laboratories to detect the $17 \mathrm{p} 11.2$ duplication/deletion include quantitative methods and indirect methods such as pulsed field gel electrophoresis, microsatellite analysis, detection of the common junction fragment by Southern blotting, detection of the common junction fragment by polymerase chain reaction (PCR), and dosage analysis of PMP-22 using semi-quantitative fluorescent PCR (STS dosage) with products analysed using either capillary electrophoresis or polyacrylamide gel electrophoresis (PAGE) and finally quantitative Real-Time dosage analysis of PMP-22 gene [7-11].

In the present study we have provide detection and analysis of $17 \mathrm{p} 11.2$ chromosome region rearrangements in CMT1 patients from Ukraine using SRT-PCR method combined with real-time quantitative PCR.

Materials and Methods. The subjects were DNAsamples extracted from peripheral blood leucocytes from Ukrainian CMT-patients and their relatives (total 57 CMT families with dominant and unclear inheritance). For the current purpose we exclude those CMT-families who revealed recessive type of inheritance. In our investigation DNA samples from unrelated volunteer non-CMT donors from different regions of Ukraine were used as normal controls. Informed consents were obtained from all individuals participating in our study.

DNA isolation from blood samples containing glugicir anticoagulant were done by standard phenol/chloroform procedures [12]. Quantity and quality of DNA probes were analyzed on ND1000 spectrophotometer (NanoDrop, USA).

STR-PCR method of CMT1A/HNPP detection. The STR loci D17S122, D17S921, D17S1358 and D17S2226 from 17p11.2 chromosomal region were used for the current study. Primer design, PCR conditions and fragment analysis using automated DNA «ALF express II» sequencer (Amersham Bioscience) of the three (CA) n STR loci allelic variants were optimized and provided as were published previously [13]. D17S2226 tetranucleotide polymorphism alleles were amplified using published primer sequences [7] and analyzed the same way as (CA) n STR loci.

Real-Time quantitative PCR method of CMT1A/ HNPP detection. For PMP22 exon 3 (target sequence) and ALB exon 12 (reference sequence) amplification we have used previously published

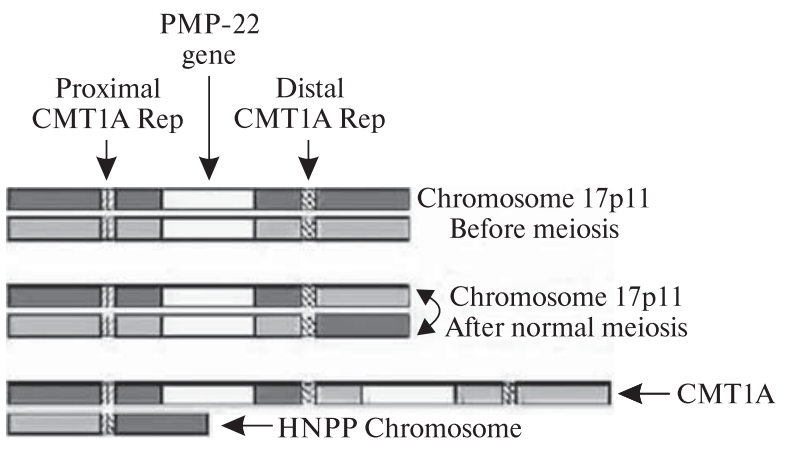

Fig. 1. 17p11.2 chromosome region rearrangements
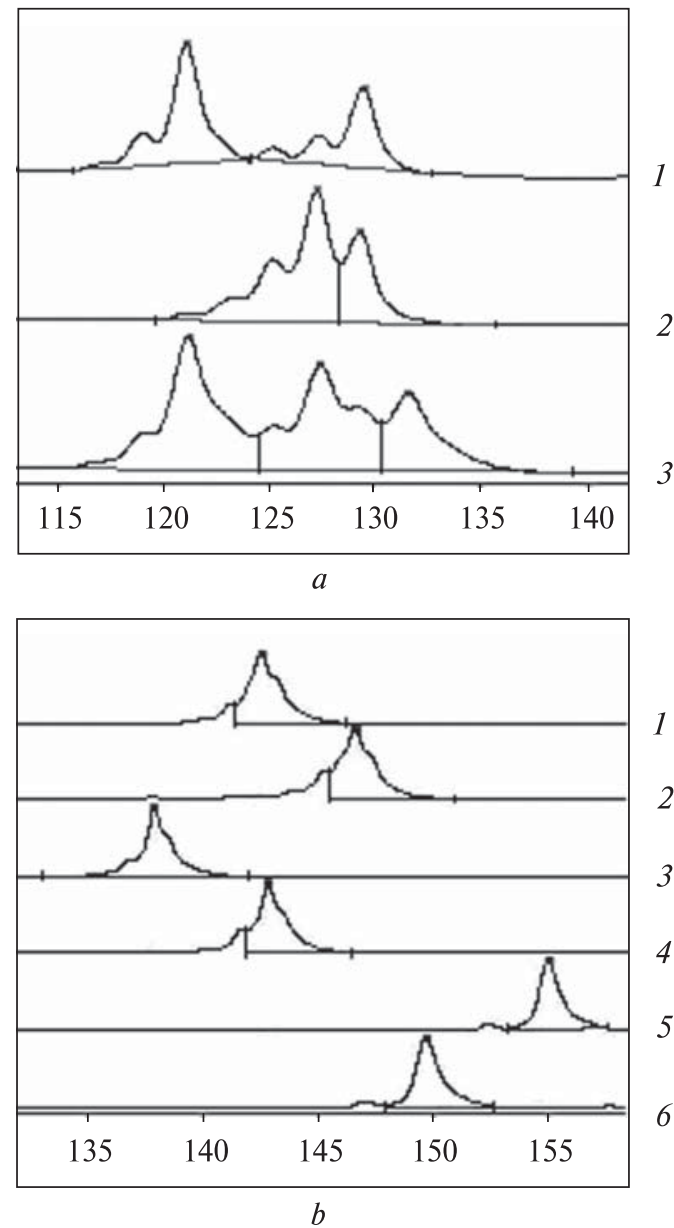

Fig. 2. Duplication and deletion detection in $17 \mathrm{p} 11.2$ region: $a$ - case with CMT1A-duplication ALF-express fluorogramm. D17S1358 locus: 1 - father, 2 - son (inherited maternal chromosome without duplication), 3 - mother (has CMT1A duplication); $b$ - case with HNPP-deletion ALF-express fluorogramm; 1, 2-D17S1358 locus, 3, 4D17S921 locus, 5, 6-D17S2226 locus, 1, 3, 5- son (has paternal chromosome with deletion), 2, 4, 6- father with deletion of $17 \mathrm{p} 11.2$ region 


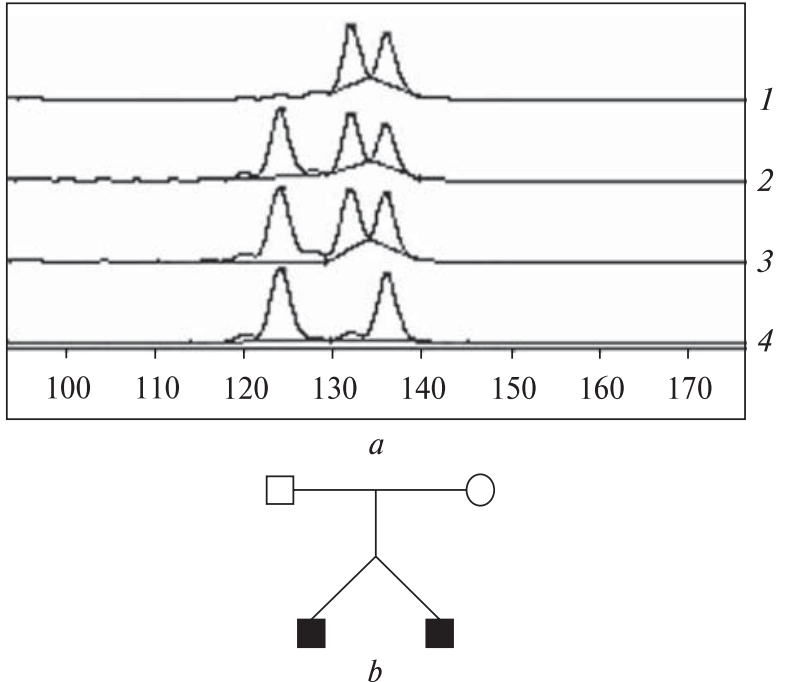

Fig. 3. Case with de novo CMT1A-duplication: $a-$ D17S2226 locus; 1 - mother (without CMT1A duplication), genotypes - 4/5; 2, 3- monozygotic twins (have CMT1A duplication), genotypes - 2/4/5; 4 - father (without CMT1A duplication), genotypes - 2/5. ALF-express fluorogramm, $6 \%$ PAAG; $b$ - pedigree of the CMT1A-family with de novo mutation

primers [11]. A 4-by-4-primer matrix (combinations of $5 \mu \mathrm{M}, 10 \mu \mathrm{M}, 20 \mu \mathrm{M}$ and $40 \mu \mathrm{M}$ of each forward and reverse primers) was analyzed to determine the optimal concentrations of both forward and reverse primers. The minimum primer concentrations that resulted in the lowest Ct-value (threshold cycle) and highest fluorescent signal $(\triangle \mathrm{Rn})$, while minimizing nonspecific amplification, were chosen as an optimal pair. The amplifications were carried out in a $50 \mu$ reaction volume containing $25 \mu \mathrm{liQ}{ }^{\mathrm{TM}}$ SYBR Green Supermix Sample (BIO-RAD, USA), $10 \mu \mathrm{M}$ forward primer and reverse primer, and $20 \mathrm{ng}$ (no less then $4 \mu \mathrm{l}$ ) of genomic DNA. In each PCR, normal controls (non-CMT) and no-template control were included. Each sample was run in duplicate for both PMP22 and ALB sequences amplification. PCR reactions were run in the $\mathrm{QQ}^{\mathrm{TM}}$ Multicolor RealTime PCR Detection System (BIO-RAD, USA). Preincubation was performed for $5 \mathrm{~min}$ at $95^{\circ} \mathrm{C}$ to denature the target DNA and activate hot-start $\mathrm{iTaq}^{\mathrm{TM}}$ DNA polymerase. DNA samples were amplified for 40 cycles of $15 \mathrm{sec}$ at $95^{\circ} \mathrm{C}$ and $1 \mathrm{~min}$ at $65^{\circ} \mathrm{C}$. The fluorescence signals were measured in Real-Time mode at the end of the elongation phase. Amplicons were run as dupli- cates in separate tubes to permit quantification of the PMP22 gene normalized to ALB gene (albu$\mathrm{min}$ ), an endogenous gene, as a control. By using a calibrator sample of normal control DNA with 2 copies of PMP22 (verified by STR-PCR method), the relative gene copy number $(\triangle \triangle \mathrm{Ct}$ ratio) of unknown sample was estimated using a $2^{-\triangle \Delta \mathrm{Ct}}$ method (Livak), because of both target and reference genes appear to be amplified with efficiencies near $100 \%$ and within $5 \%$ of each other (data not shown). The Real-Time data were processing by use the BIO-RAD iQ5 Optical System Software V 2.0 (2006).

Results and Discussion. As was mentioned above several methods have been developed in clinical laboratories for the molecular diagnosis of CMT1A and HNPP. STR-PCR methods detect three different alleles in CMT1A duplication in combination with semi-quantitative dosage measurement. Because of its advantages in cost, amount of DNA sample required, labor, and turnaround time, the STR-PCR method has been widely used for differential molecular diagnosis of CMT1A/HNPP polyneuropathy.

Using this method in our investigation the presence or absence of $1.5 \mathrm{Mb}$ CMT1A duplication or HNPP deletion was determined by allelic variants analysis of four STR-loci (D17S122, D17S921, D17S1358 and D17S2226) localized in the duplication/deletion region. Previously we provide the population study of given STRs in control Ukrainian population group [13]. The distribution of genotypes of all loci was in agreement with the expected values of the exact Hardy-Weinberg equilibrium. It has been also showed the random allele association at significance level $(p<0.05)$ for every pair of loci in Ukrainian population. However, due to limitations in sensitivity (not direct gene dosage analysis) the present STR-test system informativity for CMT1A/HNPP analysis using PCR-STR method in our population was calculated to be nearly $95 \%$.

So for current analysis of $17 \mathrm{p} 11.2$ rearrangements by STR-PCR method we selected the CMT families with autosome dominant or unclear inheritance (cases without family history of CMT) 57 families. The STR alleles discrimination had been carried out by ALF-express fragment analysis (fig. 2,a). CMT1A-duplication has been identified in 19 families with clinical CMT1 symptoms and autosome dominant inheritance with the excep- 




$a$
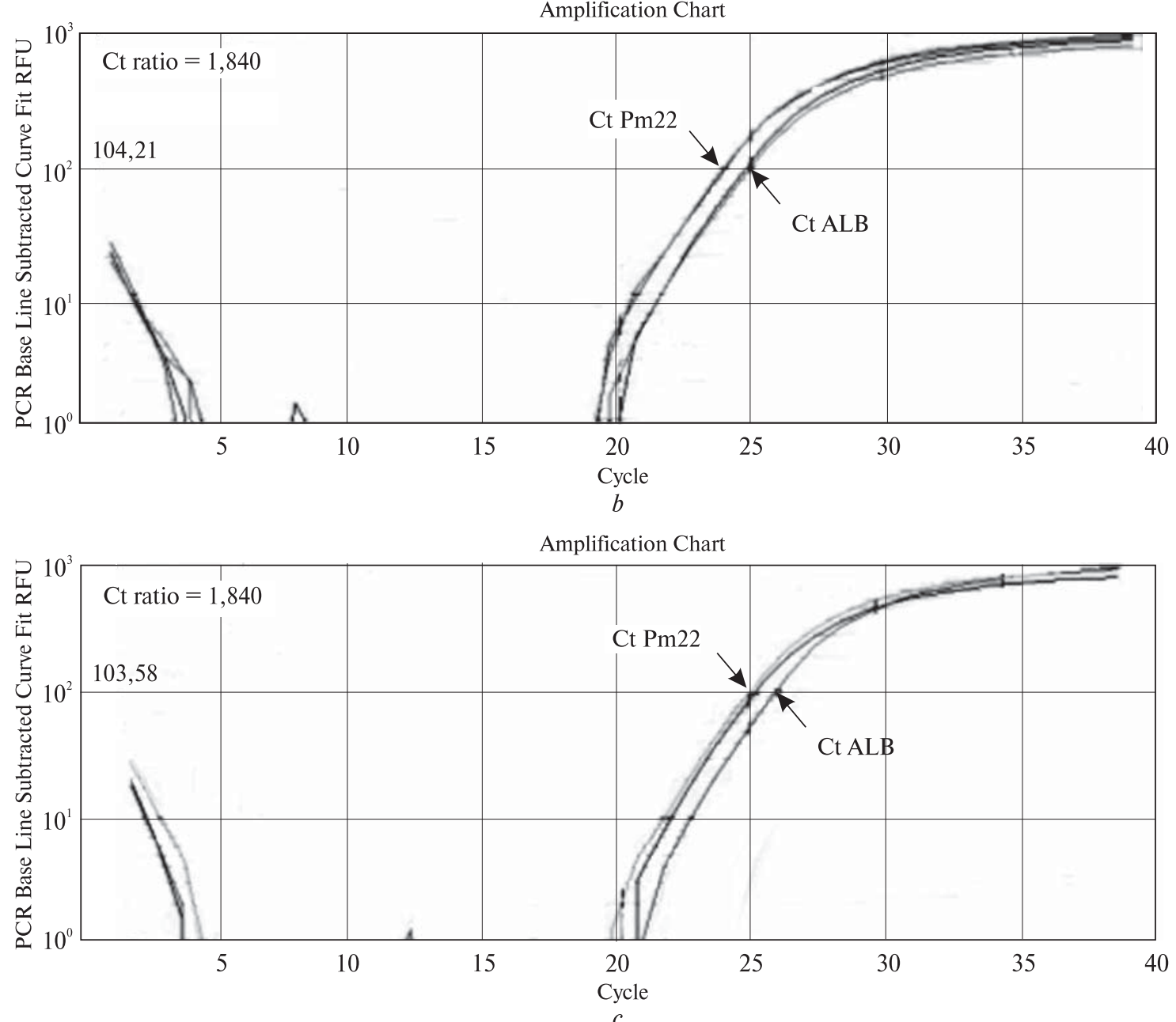

Fig. 4. Amplification plots of peripheral myelin protein 22 (PMP22) and albumin (ALB), all in duplicates: of: $a-$ normal control; $b$ - CMT1A patient with PMP22; $c$ - HNPP patient with PMP22 
Real-time data in families with de novo mutations in probands

\begin{tabular}{l|l|l|l}
\hline \multirow{2}{*}{\multicolumn{1}{c|}{ Identifier }} & \multicolumn{2}{|c|}{ Ct Mean } & \multirow{2}{*}{$\Delta \triangle$ Ct ratio } \\
\cline { 2 - 3 } & PMP22 & ALB & \\
\hline \multirow{3}{*}{ Family 1} \\
Proband's mother & 23,66 & 23,97 & \\
Proband's father & 23,60 & 23,73 & 1,24 \\
Proband & 22,68 & 23,40 & 1,64 \\
& Family 2 & \\
Proband's mother & 25,23 & 25,37 & 1,10 \\
Proband's father & 24,42 & 24,63 & 1,15 \\
Proband 1 & 24,14 & 24,87 & 1,65 \\
Proband 2 & 24,02 & 24,61 & 1,50 \\
& &
\end{tabular}

tion of two families. In these two families we supposed the 17p11.2-duplication in probands occurred due to mutation in germ cells in one of probands' parents (de novo mutation). This assumption has been made according to this mutation had not been identified in anyone of the parents (Fig. 3). In these families the paternity was confirmed by additional STR loci analysis. To adduce evidence of de novo mutation in these families additional quantitative dosage analysis has been done.

In one family HNPP-deletion have been identified (fig. 2,b). The patients (father and son) had specific HNPP clinical symptoms - recurrent neuralgic amyotrophy with sensory loss related to nerve palsies. The son has paternal chromosome with deletion (only maternal origin alleles have been revealed in every of investigated STR-loci). In this family the paternity was confirmed by additional 9Y-STR loci analysis (data not shown).

So STR-PCT method revealed to be useful for prior CMT1A/HNPP detection. But in cases with de novo mutation as well as in 2 non-informative cases (the cases with unclear dosage allele interpretation, because of probands were heterozygous only by 1 STR locus) additional method of analysis had to be used. In all questionable cases including 1 family with HNPP-deletion direct quantitative PMP22 gene dosage analysis has been provided. As a control standards DNA samples with previously PMP22 copy number identified by STR-PCR method were used ( 5 samples with 3 PMP22 copies and 6 samples with 2 PMP22 copies).

For accurate PMP22 gene dosage detection in this study we used real-time quantitative PCR with
SYBR Green I dye, as it was described previously [11] with our own modifications.

The PCR amplification plots of a normal control sample (Fig. 4, a) showed nearly identical Ct value of PMP22 triplicates, compared with that of albumin. In samples positive for the PMP22 duplication (CMT1A), the $\mathrm{Ct}$ value of PMP22 ( $\mathrm{Ct}$ Mean PMP22 = 23,91) showed a decrease of about $-0,85$, compared with that of albumin $(\mathrm{Ct}$ Mean ALB $=24,76)$ (Fig. 4, $b$ ), whereas, in samples positive for the PMP22 deletion (HNPP), the $\mathrm{Ct}$ value of PMP22 (Ct Mean PMP22 = 25,86) showed an increase of about 0,97 , compared with that of albumin (Ct Mean ALB $=24,89$ ) (Fig. 4, c). The $\Delta \triangle \mathrm{Ct}$ ratio means in normal controls, including asymptomatic normal family members, were $0,93-1,30$. The $\Delta \triangle \mathrm{Ct}$ ratio means in CMT1A patients were $1,50-2,04$. The $\triangle \triangle \mathrm{Ct}$ ratio means in 2 HNPP patients were 0,54 and 0,57 . No overlap was observed between CMT1A or HNPP patients and normal controls.

Results of real-time quantitative PCR analysis results confirmed the STR-PCR analysis in described HNPP-family as well as the absence of CMT1A duplication in previously non-informative samples. We also verified our hypothesis that in two families under investigation $17 \mathrm{p} 11.2$-dupliation in probands appeared as de novo mutation (Table). In both families each of parents had 2 PMP22 gene copies $(\triangle \triangle \mathrm{Ct}$ ratios were in range $1,1-1,3)$, whereas a sick a girl from one family and two twins from the other had 3 copies of PMP22 gene ( $\triangle \triangle \mathrm{Ct}$ ratios were in range 1,$64 ; 1,65 ; 1,50$ correspondingly).

So it has been shown that detection of the PMP22 duplication and deletion by real-time quantitative PCR is fast and sensitive and lets us fulfil direct quantitative gene dosage analysis. The method takes only $2 \mathrm{hr}$ and does not require postPCR processing. In addition, DNA samples of parents are not required to determine $17 \mathrm{p} 11.2$ rearrangements in proband. This advantage is the most useful in HNPP-cases if only proband's DNA is available for $17 \mathrm{p} 11.2$-deletion analysis.

Conclusions. The methods of $17 \mathrm{p} 11.2$ duplication/deletion identification have been elaborated: STR allelic variants analysis and direct PMP22 gene dosage measuring by means of quantitative RealTime PCR. It has been shown that Real-Time PCR using SYBR Green I dye is highly sensitive, specif- 
ic, and reproducible in detecting PMP22 duplication and deletion in patients with CMT1A and HNPP. We also indicate high level of de novo cases with 17p11.2-duplication - in 2 of 19 CMT1Afamilies. It has been shown the $17 \mathrm{p} 11.2$ chromosome region duplication/deletion association with CMT1A and HNPP clinical phenotypes which may be used in differential diagnosis of this type of CMT polyneuropathy.

\section{Н.В. Грищенко, Л.А. Лившии \\ АНАЛИЗ ХРОМОСОМНЫХ ПЕРЕСТРОЕК В ОБЛАСТИ 17p11.2 У БОЛЬНЫХ ШМТ1 ИЗ УКРАИНЫ}

Проведена детекция и анализ хромосомных перестроек области 17p11.2 у пациентов с болезнью ШаркоМари-Тус (ШМТ) из Украины. Разработаны два взаимодополняющих метода идентификации дупликаций/делеций в области 17p11.2: анализ аллельных вариантов STR-локусов и прямой анализ дозы гена PМР22 с использованием ПЦР в реальном времени. Выявлен высокий уровень de novo дупликаций в указанном хромосомном регионе. Показана ассоциация дупликаций/делеций в области $17 \mathrm{p} 11.2$ с клиническими фенотипами ШМТ1А и НNPP, что может быть использовано для дифференциальной диагностики упомянутых типов полиневропатии ШМТ.

\section{Н.В. Грищенко, Л.А. Лівшиць АНАЛІЗ ХРОМОСОМНИХ ПЕРЕБУДОВ У ДІЛЯНЦІ 17p11.2 У ХВОРИХ ШМТ1 3 УКРАЇНИ}

Проведено детекцію та аналіз хромосомних перебудов ділянки 17p11.2 у пацієнтів з хворобою ШаркоМарі-Тус (ШМТ) з України. Розроблено два взаємодоповнюючі методи ідентифікації дуплікацій/делецій у ділянці 17p11.2: аналіз алельних варіантів STR-локусів та прямий аналіз дози гена PMP22 із використанням ПЛР у реальному часі. Виявлено високий рівень de novo дуплікацій цієї хромосомної ділянки. Показано ассоціацію дуплікацій/делецій у ділянці $17 \mathrm{p} 11.2$ із клінічними фенотипами ШМТ1А та HNPP, що може бути використано для диференційної діагностики даних типів поліневропатії ШМТ.

\section{REFERENCES}

1. Skre H. Genetic and clinical aspects of Charcot-MarieTooth's disease // Clin. Genet. - 1974. - 6, № 2. P. 98-118.

2. Bouche P. How to interpret the electromyogram (in neuromuscular diseases) // Rev. Prat. 1983. - 33, № 11. - P. 549-555.
3. Boerkoel C.F., Takashima H., Garcia C.A. et al. Charcot-Marie-Tooth disease and related neuropathies: mutation distribution and genotype-phenotype correlation // Ann. Neurol. - 2002. - 51. № 2. - P. 190201.

4. Chance P.F., Alderson M.K., Leppig K.A. et al. DNA deletion associated with hereditary neuropathy with liability to pressure palsies // Cell. - 1993. - 72, № 1. P. $143-51$

5. Pentao L., Wise C.A., Chinault A.C., Patel P.1., Lupski $J . R$. Charcot-Marie-Tooth type IA duplication appears to arise from recombination at repeat sequences flanking the $1.5 \mathrm{Mb}$ monomer unit // Nature Genet. - 1992. 2. - P. 292-300.

6. Lupski JR. Charcot-Marie-Tooth disease: lessons in genetic mechanisms // Mol. Med. - 1998. - 4, № 1. P. 3-11.

7. Badano J.L., Inoue K., Katsanis N., Lupski J.R. New polymorphic short tandem repeats for PCR-based Charcot-Marie-Tooth disease type 1A duplication diagnosis // Clin. Chem. - 2001. - 47, №5. - P. 838843.

8. Kashork C.D., Lupski J.R., Shaffer L.G. Prenatal diagnosis of Charcot-Marie-Tooth disease type 1A by interphase fluorescence in situ hybridization // Prenat Diagn. - 1999. - 19. - P. 446-449.

9. Hensels G.W., Janssen E., Hoogendijk J.E. et al. Quantitative measurement of duplicated DNA as a diagnostic test for Charcot-Marie-Tooth disease type la // Chin. Chem. - 1993. - 39. - P. 1845-1849.

10. Rowland J.S., Barton D.E., Taylor G.R. et al. A comparison of methods for gene dosage analysis in HMSN type 1 // Med. Genet. - 2001. - 38. - P. 90-95.

11. Sang-Wun Kim, Kwang-Soo Lee, Hyun-Seok Jin et al. Rapid detection of duplication/deletion of the PMP22 gene in patients with Charcot-Marie-Tooth disease type $1 \mathrm{~A}$ and hereditary neuropathy with liability to pressure palsy by real-time quantitative PCR using SYBR green I dye // J. Korean Med. Sci. - 2003. - 18. P. 727-732.

12. Maniatis T., Fritsch E.F., Sambrook J. Molecular cloning : a laboratory manual. - Cold Spring Harbor Laboratory, 1982. - $545 \mathrm{p}$.

13. Grishchenko N.V., Bychkova A.M., Pichkur N.A et al. Study of the duplication of 17P11.2-12 chromosome region for the patients with hereditary motor and sensory neuropathy type 1A // Cytol. and Genet. - 2003. 37, № 6. - P. 55-59.

14. Hryshchenko N.V., Kravchenko S.A., Livshits L.A. Polymorphic short tandem repeats for PCR-based diagnosis of the Charcot-Marie-Tooth 1A duplication in Ukraine // Cytol. and Genet. - 2005. - 39, № 5. P. 56-61.

Received 11.02.08 